\title{
Sedick Isaacs
}

The passing of our colleague and friend Sedick Isaacs on 18 October 2012 signified the end of an era, not only for Health Informatics in South Africa, Africa and internationally and to his family, but also in the broader public life of South Africa.

Behind the very quiet and unassuming exterior was an extraordinarily bright and active mind, evident in the form of deeply insightful comments on whatever topic was under discussion. This formidable intellect sometimes resulted in Sedick losing an audience because those listening were unable to keep up with the sophistication of his reasoning. But he was primarily a teacher, an educator. He often, as a result, formed his inputs to his audiences with the aim of taking them along with him to solve whichever problem was in front of them. The audiences could consist of one or many people, ranging in age from toddlers (especially his daughters, and more lately his granddaughters), through to the many pupils whom he taught, to students whom he supervised and mentored, and his colleagues in a wide range of disciplines. Even after his retirement from Groote Schuur Hospital and the University of Cape Town where he had been a highly respected biostatistician, he continued to teach and mentor. He tutored the children of friends and family in high school mathematics every Saturday afternoon for decades, and was always available to fill in when a school needed to replace a teacher temporarily. One of these postings was as a Grade 5 teacher at a local primary school, at the end of which he and his pupils were very sad to take their leave of each other. It is fitting and a recognition of Sedick's extraordinary ability to enable people to reach their own solutions that his last formal appointment was at the University of the Western Cape, where he had primary responsibility for supporting university staff in improving their credentials through completion of their doctorates - despite difficult circumstances, including heavy teaching loads.

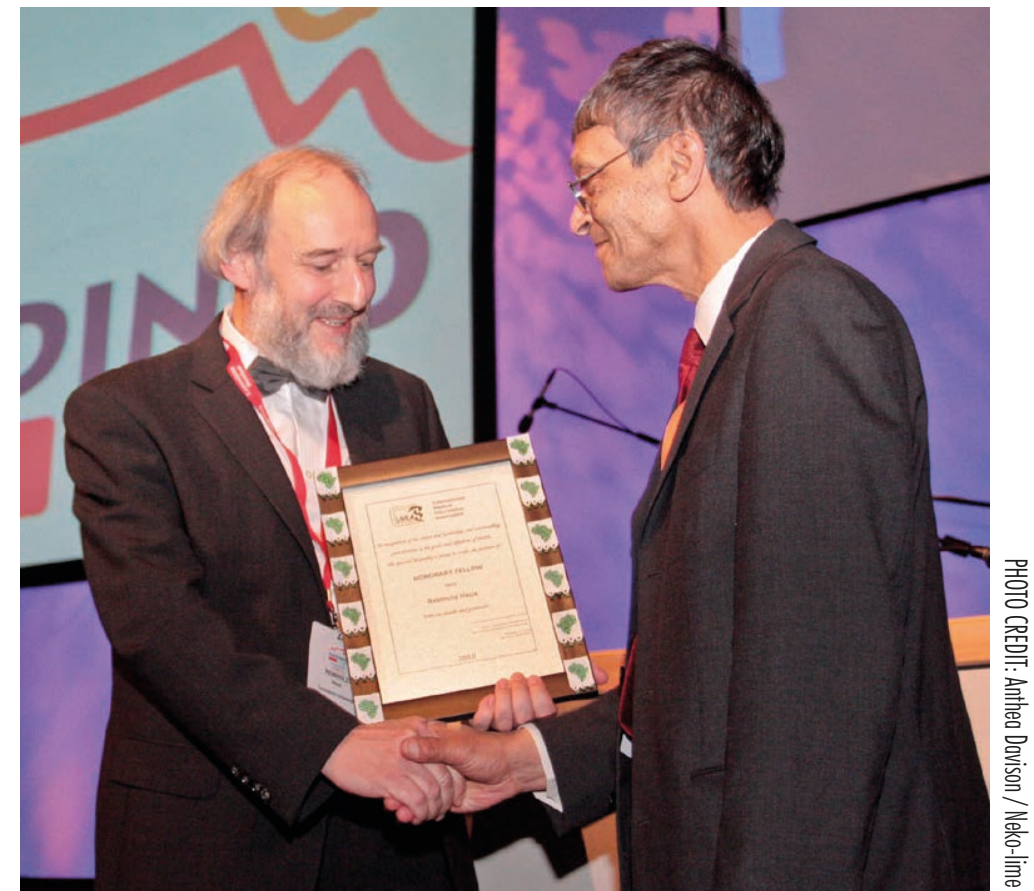

It is now well known that Sedick was a political prisoner on Robben Island for 13 years. While this was a very difficult experience, as reflected in his book published in $2010^{1}$, and continuing for many years after his release in 1977 when he was subjected to heavy personal restrictions, Sedick refused to be a victim, and always found ways of rising above his environment, for example, by taking on what became a life's mission, that of teaching and mentoring. Two of the enduring marks of his long imprisonment were his struggle to cope with cold conditions; and his unending interest in and love for his own children and grandchildren, and the children of his family and friends - one of the major deprivations of prison life being almost total lack of contact with children.

In the Health Informatics world, Sedick was a founding member of the South African Medical Informatics Group, later the South

Isaacs, S (2010). Surviving in the Apartheid Prison: Flash backs of an earlier life. Xlibris Corporation, Cape Town.
African Health Informatics Association (SAHIA) and served in various capacities, including SAHIA President. He was president of the IMIA HELINA region until his death, having played a pivotal role in its formation, and being an ongoing source of guidance and support for the HELINA council and the wider HELINA family. Through HELINA, he participated in IMIA activities formally through the General Assembly and informally through personal contacts and relationships, always supported by his wife Maraldea. The extent of Sedick's influence and the high regard in which he is held in the IMIA family are reflected in his being made an IMIA fellow in 2010, and in the many messages and tributes received on his passing from all over the world.

Those of us left behind have a shining example to follow, and an unavoidable responsibility to build on the legacy of a truly great man. Hamba kahle, Sedick.

Lyn Hanmer, South African Health Informatics Association April 2013 